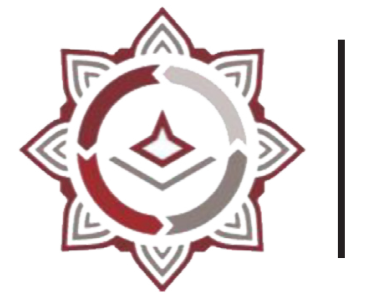

BISNIS: Jurnal Bisnis dan Manajemen Islam

P-ISSN: 2442-3718, E-ISSN: 2477-5533

Volume 9, Nomor 2, Desember 2021 (PP : 279-300)

https://journal.iainkudus.ac.id/index.php/Bisnis/index

http://dx.doi.org/10.21043/bisnis.v9i2.12038

\title{
Analisis Kinerja Keuangan Pelaku Usaha pada UD. Al Qudsy Manggis
}

\author{
Widi Savitri Andriasari ${ }^{1}$, Ahmad Syifaul Aziz ${ }^{2}$, Siti Lailatu Nurjannah ${ }^{3}$ \\ Nia Monica Febriana ${ }^{4}$, Peni Safitri ${ }^{5}$ \\ Institut Agama Islam Negeri Kudus $s^{1,2,3,4,5}$ \\ andriasavitri@gmail.com
}

\begin{abstract}
This research aims to find out and analyze how financial performance uses liquidity ratio and profitability ratio in UD AL-Qudsy Manggis. Approaches in research that use descriptive research using quantitative data. Research data collection techniques use documentation studies. The results of research conducted showed that the profitability ratio in 2018 to 2020 with a Net Profit Margin (NPM) value of $50.23 \%$ is very good. While the liquidity ratio is indicated by the average Current Ratio value of 2018-2020 of 274.52\% showing Very Good, and Quick Ratio of 260.68\% Very Good. The current ratio for three years is a value that has reached the Standard of Trading Companies. This shows that the company is able and able to pay its current debts with current assets and cash available at Al-Qudsy Manggis company. In terms of profitability, the return on investment (ROI) is $46.30 \%$ in good value because the value has reached the Standard, while the return on equity (ROE) in 2020 is peaking and is said to be very good because the value exceeds the Standard which is $60.91 \%$ the value is not significant because the average (ROE) 2018-2020 is $60.84 \%$. Judging from these indicators, financial performance based on the Decree of the Minister of State for Cooperatives and Small and Medium Enterprises on (UMK) law No.14 of 2009 can be concluded that the profitability level of UD Al-Qudsy Manggis in the category is very good because the indicator value is above its standards. The ability to generate corporate profits with the company's capital invested in its business is very high and the ability of the company in generating corporate profits has been maximized.
\end{abstract}

Keywords: Financial Performance, Liquidity, and Profitability 


\begin{abstract}
Abstrak
Penelitian ini bertujuan untuk mengetahui dan menganalisis bagaimana kinerja keuangan menggunakan Rasio Likuiditas dan Rasio Profitabilitas pada UD AL-Qudsy Manggis. Pendekatan penelitian ini menggunakan penelitian deskriptif dengan data kuantitatif. Teknik pengumpulan data penelitian menggunakan studi dokumentasi. Hasil penelitian menunjukan bahwa rasio profitabilitas pada tahun 2018 sampai 2020 dengan nilai Net Profit Margin (NPM) sebesar 50,23\% Sangat Baik. Sedangkan rasio likuiditas dengan nilai Current Ratio rata-rata 2018-2020 sebesar 274,52\% menunjukkan Sangat Baik, dan Quick Ratio sebesar 260,68\% berarti Sangat Baik. Current ratio selama tiga tahun merupakan nilai yang sudah mencapai Standar Perusahaan dagang. Hal tersebut menunjukan perusahaan mampu dan dapat membayar hutang lancarnya dengan aktiva lancar dan kas yang tersedia di perusahaan Al-Qudsy Manggis. Profitabilitas yaitu return on investment (ROI) sebesar $46,30 \%$ di nilai baik karena nilainya sudah mencapai Standar. Sedangkan return on equity (ROE) tahun 2020 mengalami puncak dan dikatakan sangat baik karena nilainya melebihi Standar yaitu 60,91\%, namun nilai tersebut tidak signifikan karena rata-rata (ROE) 20182020 adalah 60,84\%. Hasil tersebut menunjukan bahwa tingkat profitabilitas UD AlQudsy Manggis dalam kategori sangat baik karena nilai indikator lebih tinggi dari standar. Didukung oleh kemampuan dalam menghasilkan laba dengan modal perusahaan sendiri yang diinvestasikan kedalam usaha sangat tinggi serta kemampuan dalam menghasilkan laba perusahaan sudah maksimal. Dengan demikian dapat disimpulkan bahwa kinerja keuangan UD Al-Qudsy Manggis sangat baik.
\end{abstract}

Keywords: Kinerja Keuangan, Likuiditas, dan Profitabilitas

\title{
PENDAHULUAN
}

Badan usaha perseorangan adalah badan usaha yang banyak digunakan di Indonesia, khususnya pengusaha kecil dan pengusaha menengah. Didalam dunia bisnis, masyarakat telah mengenal dan menerima bentuk badan usaha perseorangan yang disebut usaha dagang (UD) yang bermakna badan usaha perusahaan yang dimiliki oleh satu orang saja yang menjadi pemilik badan usaha itu dan yang menjalankan perusahaan. Dengan demikian modal usaha tersebut hanya dimiliki oleh satu orang pula. Jika didalam perusahaan tersebut banyak orang bekerja, mereka hanyalah pembantu pengusaha dalam perusahaan berdasarkan perjanjian kerja.

Pelaku usaha biasanya lebih memfokuskan untuk memperoleh keuntungan dari bisnis yang sedang dijalankannya. Utuk mencapai keuntungan yang diperoleh dapat ditentukan dengan kinerja perusahaan yang akan dijadikan sebagai 
dasar pengambilan keputusan dari pihak internal dan eksternal. Potensi untuk mencapai keuntungan perusahaan pada periode tertentu dapat disebut dengan profitabilitas. Potensi perusahaan untuk mencapai keuntungan merupakan bagian dari kinerja perusahaan.

Rasio likuiditas merupakan suatu alat untuk mengukur potensi kinerja perusahaan untuk memenuhi kewajiban utang jangka pendek pada saat jatuh tempo. Likuiditas tidak hanya berhubungan dengan keadaan semua keuangan perusahaan, tetapi juga berkaitan dengan kemampuannya untuk mengubah asset (aktiva lancer) tertentu menjadi uang tunai (kas) dengan mudah dan cepat.

Rasio profitabilitas dapat digunakan sebagai alat untuk mengukur kinerja keuangan perusahan, hal ini dapat dilihat dari daya tarik usaha yang merupakan salah satu indikator penting dalam sebuah persaingan usaha, yang dapat diukur dari porfitabilitas usaha, seperti ROA, ROE dan NPM. Semakin tinggi rasio likuiditas, maka akan menarik pendatang baru untuk masuk dalam dunia usaha, sehingga pada hal persaingan tersebut akan membuat rate of return lebih mengarah pada kesetimbangan (Gale, 1972).

Penting adanya laporan keuangan dalam menilai kesetimbangan keuangan perusahaan, maka laporan keuangan perlu di rangkai secara seksama agar terhindar dari kekeliruan. Para pihak yang memiliki kepentingan dapat menginterprestasikan laporan keuangan dengan persepsi yang sama. Dalam hal ini perlu adanya suatu struktur laporan keuangan untuk memudahkan para pelaku usaha dalam menyajikan laporan keuangan perusahaan yang baik dan benar.

UD. Al Qudsy Manggis adalah usaha dagang yang bergerak pada produksi makanan dan minuman, yang produknya terdiri dari sirup manggis, snack, roti dan juga kecap cap manggis. Melihat system keuangan pada UD Al Qudsy Manggis yang masih menjadi satu dan system penyusunan laporan yang kurang mendetail untuk itu maka penulis ingin meneliti apakah kinerja keuangan diperusahaan Al Qudsy Manggis sudah berjalan dengan baik dan benar.

Salah satu cara untuk menghitung efisiensi kinerja keuangan perusahaan dalam manajemen keuangan yaitu dengan menggunakan analisa rasio likuiditas dan rasio profitabilitas. Analisis rasio tersebut dapat digunakan untuk menilai besar kecilnya produktifitas usaha pada sebuah perusahaan. Untuk menilai tingkat profitabilitas ini dapat menggunakan beberapa kriteria antara lain yaitu Net Profit Margin (NPM), Return On Assets (ROA), Return on Equity (ROE), Current Asset dan Quick Asset. 
Dalam penelitian ini dapat ditarik rumusasn masalah sebagai berikut: Bagaimana kinerja keuangan UD. Al Qudsy Manggis pada tingkat rasio likuiditas dan bagaimana kinerja keuangan pada UD. Al Qudsy Manggis pada tingkat rasio profitabilitas.

Adapun tujuan penelitian ini yaitu untuk mengetahui dan menganalisa kinerja keuangan UD. Al Qudsy Manggis menggunakan perhitungan rasio likuiditas dan rasio profitabilitas. Hasil dari penelitian ini diharapkan dapat memberikan manfaat untuk dijadikan referensi pada penulis selanjutnya, terutama pada bidang manajemen keuangan yang berkaitan dengan penilaian kinerja keuangan perusahaan, dan memberikan manfaat secara teoritis bagi mahasiswa dalam mengetahui secara rinci pada sistem keuangan di perusahaan untuk pembelajaran dan bisa menambah wawasan dalam bidang manajemen keuangan.

\section{KAJIAN LITERATUR}

\section{Laporan Keuangan}

Kegiatan akhir dari serangkaian proses penyusunan dan pengihtisaran suatu data transaksi bisnis disebut dengan laporan keuangan. Pada dasarnya laporan keuangan merupakan suatu alat yang digunakan dalam mengkomunikasikan data keuangan terhadap suatu pihak yang dianggap penting dari hasil sistem akuntansi (Hery, 2016). Laporan keuangan dianggap penting karena memberikan input (informasi) yang bisa digunakan dalam pengambilan keputusan. Pihak yang terlibat kepentingan dalam laporan keuangan yaitu penanam modal atau calon investor, donator atau calon donator, serta manajemen perusahaan yang bersangkutan. Laporan keuangan diperlukan dalam memberikan informasi mengenai risiko, profitabilitas dan timing dari aliran kas yang dihasilkan suatu perusahaan. (Hanafi, Mamdun M, 2016).

\section{Analisis Kinerja Keuangan}

Alat analisis dapat digunakan untuk menilai kinerja keuangan, berdasarkan tekniknya dibagi menjadi (Utama, Erpan Rizky, 2019):

1. Analisis perbandingan laporan keuangan, adalah cara menganalisis dengan membandingan dua atau lebih periode mengenai laporan keuangan dengan memastikan adanya perubahan, terkait jumlah ataupun presentasi. 
2. Analisis rasio keuangan, yaitu cara menganalisis keuangan untuk mendapati adanya hubungan yang terjadi secara individual ataupun simultan antara item tertentu di neraca dan laporan laba rugi.

\section{Rasio Keuangan}

Irham Fahmy (2015) mendefinisikan rasio keuangan sebagai hasil dari membandingkan suatu jumlah dengan jumlah yang lain (Utama, Erpan Rizky, 2019). Rasio keuangan dapat diartikan suatu aktivitas dalam membandingan angka-angka yang tercatat di laporan keuangan dengan membagikan satu angka dengan angka yang lain. Analisis rasio keuangan merupakan bentuk analisis kuantitatif yang diperlukan dalam mengevaluasi beragam aspek kinerja operasi serta keuangan perusahaan menurut informasi yang berada di laporan keuangan perusahaan meliputi laporan laba rugi, neraca, laporan aliran kas (Tarumasely \& Siswati, 2021). Analisis keuangan memiliki manfaat diantaranya: digunakan sebagai alat dalam menilai kinerja dan performa perusahaan, sebagai pijakan dalam perencanaan, sebagai alat untuk menguji keadaan suatu perusahaan dari aspek keuangan, sebagai penilaian terhadap pihak pemangku kepentingan organisasi, dan digunakan dalam mengukur adanya potensi resiko yang dihadapi para kreditor berkaitan dengan penyetoran bunga dan pengembaliaan pinjaman pokok (Anwar et al., 2020).

\section{Rasio Profitabilitas}

Rasio profitabilitas merupakan rasio yang menjelaskan mengenai kemampuan perusahaan dalam memperoleh laba melalui segenap kemampuan serta beberapa sumber kegiatan yang terdiri dari penjualan, dana, modal serta jumlah pegawai (Khamidah, 2015). Rasio profitabilitas atau sebutan lainnya yaitu rasio keuntungan digunakan untuk mengukur berapa besar kemampuan untuk mencari keuntungan atau laba bagi perusahaan dalam periode tertentu (Anwar et al., 2020). Dengan demikian disimpulkan bahwa rasio profitabilitas adalah rasio yang dapat digunakan dalam menilai kemampuan dan kesuksesan perusahaan untuk menghasilkan laba ataupun keuntungan.

Untuk menghitung tingkat rasio profitabilitas ada beberapa rasio yang digunakan dalam perusahaan: 


\section{1) Net Profit Margin (NPM)}

Merupakan rasio profitabilitas yang digunakan dalam menilai kemampuan perusahaan menghasilkan laba bersih pada setiap penjualan tertentu.

$$
N P M=\frac{\text { Laba Bersih }}{\text { Penjualan }} \times 100 \%
$$

Rasio ini diartikan juga sebagai kemampuan perusahaan untuk menekann biaya-biaya yang berada diperusahaan pada periode tertentu. Profit margin yang tinggi menunjukkan adanya kemampuan dalam menghasilkan keuntungan yang tinggi terhadap tingkat penjualan. Sedangkan rasio yang rendah berarti terjadi ketidakefesiennya manajemen (Hanafi, Mamdun M, 2016).

\section{2) Return On Assets (ROA)}

ROA adalah rasio yang digunakan untuk mengukur kemampuan perusahaan dalam memperoleh laba bersih berdasarkan tingkat asset tertentu. ROA disebut juga ROI (Return on Investment) (Hanafi, Mamdun $M, 2016)$. Untuk menghitung rasio dengan rumus berikut :

$$
R O A=\frac{\text { Laba Bersih }}{\text { Total Aktiva }} \times 100 \%
$$

Return on assets menampilkan efisiensi dimana perusahaan mengelola asset ekuitas dan kewajiban, investor akan memandang seberapakah efisiensi sesuatu perusahaan dalam mengatur asset, semakin tinggi tingkatan ROA maka akan memberikan dampak terhadap volume penjualan saham, maksudnya tinggi rendahnya ROA dapat berpengaruh terhadap minat investor dalam melaksanakan investasi sehingga dapat berpengaruh juga terhadap volume penjualan saham perusahaan begitu pula sebaliknya (Khamidah, 2015).

\section{3) Return On Equality (ROE)}

ROE dijadikan proses dalam mengukur kemampuan perusahaan dalam memperoleh laba bersih berdasarkan jumlah modal tertentu. 
Laporan ini adalah patokan dari profitabilitas dari perspektif pemegang saham. Semakin tinggi rasio ini, semakin baik keadaan perusahaan.

$$
\text { ROE }=\frac{\text { Laba Bersih }}{\text { Jumlah Modal }} \times 100 \%
$$

\section{Rasio Likuiditas}

Rasio likuiditas mengukur likuiditas jangka pendek suatu perusahaan dengan memeriksa ukuran aset lancar relatif perusahaan terhadap kewajiban lancarnya (Hanafi, Mamduh M, 2016). Rasio likuiditas juga dapat diartikan sebagai kemampuan perusahaan yang menggambarkan terpenuhinya kewajiban jangka pendek. Rasio likuiditas terdiri dari:

\section{1) Current Ratio (Rasio Lancar)}

Rasio ini menentukan tentang sejauh mana aktiva lancer menutupi kewajiban lancar. Adanya perbandingan antara aktiva lancer dengan hutang lancer yang semakin besar, maka dalam menutupi kewajiban jangka pendek perusahaan juga akan semakin tinggi. Rasio ini bisa terbuat dalam wujud berapa kali ataupun wujud persentase.

$$
C R=\frac{\text { Aktiva Lancar }}{\text { Kewajiban Lancar }} \times 100 \%
$$

\section{2) Quick Ratio (Acid Test Ratio)}

Quick Ratio adalah perbandingan dari (aktiva-persediaan) dengan hutang lancar. Rasio ini ialah mengukur keahlian perusahaan untuk terpenuhinya kewajiban-kewajibannya dengan tidak memperhitungkan persediaan, sebab persediaan membutuhkan waktu yang relative lama dalam merealisir sebagai uang kas. Standar Quick Ratio 100\% dipandang baik dalam menunjukan kondisi keuangan dalam jangka pendek (Khamidah, 2015). Rumus QR:

$$
\text { Quick Ratio }=\frac{\text { Aktiva lancar }- \text { Persediaan }}{\text { Hutang Lancar }} \times 100 \%
$$

\section{Standar Penilaian Kinerja Keuangan}

Kinerja keuangan bagi perusahaan berhubungan dengan pengukuran dan juga penilain kinerja. Pengukuran kinerja merupakan suatu kualifikasi serta efisiensi dan 
daya guna bagi perusahaan dalam mengoperasikan bisnis sepanjang perode akuntansi, untuk investor data mengenai kinerja keuangan perusahaan bisa dipergunakan dalam melihat apakah mereka hendak mempertahankan investasi di perusahaan atau malah mencari alternative yang lain (Utama, Erpan Rizky, 2019). Penilaian mengenai kinerja keuangan dalam perusahaan, penelitian ini Berdasarkan Keputusan Menteri Koperasi dan Usaha Kecil dan Menengah (UKM) No. 1 tahun 2009.

\section{METODE PENELITIAN}

\section{Objek Penelitian}

UD. Al Qudsy Manggis adalah usaha dagang yang bergerak pada produksi makanan dan minuman, yang produknya terdiri dari sirup manggis, snack, roti dan juga kecap cap manggis. Usaha yang berdiri pada tahun 2016 ini didirikan oleh Bapak Saiful Aviv yang mana usaha ini beralamat di Desa Ngembal Kulon, Kudus Jl. Poncowati No. 545 Rt 01 Rw 04. Perusahaan selalu mempertahankan kualitas dalam segala aspek agar terciptanya hasil yang berkualitas juga.

\section{Populasi dan Sampel}

Populasi merupakan keseluruhan dari subyek penelitian. Populasi yaitu semua data yang menjadi perhatian pada suatu lingkup dan waktu yang telah ditentukan (Syafi'I, Asrof, 2005). Pada penelitian ini populasi yang diambil mengenai laporan data keuangan UD. Al Qudsy Kudus pada tahun 2018-2020 secara keseluruhan data tersebut akan dijadikan sebagai populasi pada penelitian terhadap kinerja keuangan.

Sampel merupakan sekelompok kecil yang menjadi pengamatan dan bagian dari populasi, sehingga sifat dan karekteristik populasi dimiliki oleh sempel (Fathoni, Abdurahmat, 2005). Sampel yang digunakan yaitu laporan neraca dan laporan laba rugi tahun 2018-2020 UD. Al Qudsy Kudus.

\section{Teknik Pengumpulan Data}

Teknik pengumpulan data yaitu cara terpenting dalam melakukan penelitian dengan tujuan untuk mendapatkan data. Pengumpulan data yang sesuai dengan penelitian ini yaitu dengan:

1. Library Research (Studi Kepustakaan), pengumpulan data bersumber dari bahan pustaka dengan membaca dan mempelajari literature, skripsi, jurnal, e-book, e-jurnal, dll yang berhubungan dengan masalah penelitian 
2. Field Research, pengumpulan data secara langsung pada objek penelitian.

a. Observasi : pengamatan secara langsung pada objek penelitian dengan alat indra, agar memperoleh data primer dab bukti nyata.

b. Wawancara : kegiatan tanya jawab dalam bentuk diskusi dan percekapan kepada pihak yang terkait.

c. Dokumentasi : pengumpulan data dengan mencatat dokumen dan transkip penjualan yang diperlukan dari perusaan sesuai dengan pembahsan pada penelitian (Andjarwati \& Nur hakim, 2018).

\section{Metode Analisis Data}

Metode yang digunakan untuk penelitian ini yaitu metode analisis deskriptif kuantitatif yaitu penelitian yang dilakukan dengan mencatat serta menganalisis data hasil dari penelitian secara eksak dengan melibatkan perhitungan statistic. Tujuan penelitian deskriptif kuantitatif yaitu untuk mendiskripsikan suatu kejadian dengan menggunkan angka yang menggambarkan karakteristik subjek yang diteliti (Audina \& Khotimah, 2021). Analisisi deskriptif kuantitatif merupakan analisis berbasis laporan yang dapat menentukan tingkat likuiditas dan profitabilitas sebagai dasar pengambilan keputusan, data yang dianalisi adalah profitabilitas dan likuiditas dalam mengevaluasi kinerja pembentukan keuangan.

Definisi operasional

1. Rasio Profitabilitas adalah rasio yang menggambarkan tingkat diperolehnya keuntungan dibanding aktiva penjualan. Yang dibagi menjadi tiga rasio:

a. NPM adalah tingkat pengembalian yang mengukur rasio laba bersih terhadap pendapatan dari penjualan.

b. ROA digunakan daalm menilai persentase laba yang didapat dari total asset sehingga dalam mengelola asset bsa terlihat persentase rasio ini.

c. ROE, mengevaluasi kemampuan perusahaan untuk memperoleh keuntungan dari investasi pemegang saham, dinyatakan sebagai persentase. (Utama, Erpan Rizky, 2019).

2. Rasio Likuiditas, diartikan sebagai kemampuan asset lancar untuk menutupi kewajiban jangka pendek perusahaan. 
a. Current Ratio, menunjukan bagaimana aktiva lancar dapat menutupi kewajiban lancar.

b. Quick Ratio, perbandingan dari (aktiva lancar-persedian) dnegan hutang lancar (Khamidah, 2015).

3. Analisis Standar Penilaian Kinerja Keuangan

Indikator kinerja keuangan berdasarkan Keputusan Menteri Negara Koperasi dan Undang-Undang tentang Usaha Kecil dan Menengah (UMK) no. 14 tahun 2009, khususnya meliputi:

Tabel 1 Standar Penilaian Kinerja Keuangan

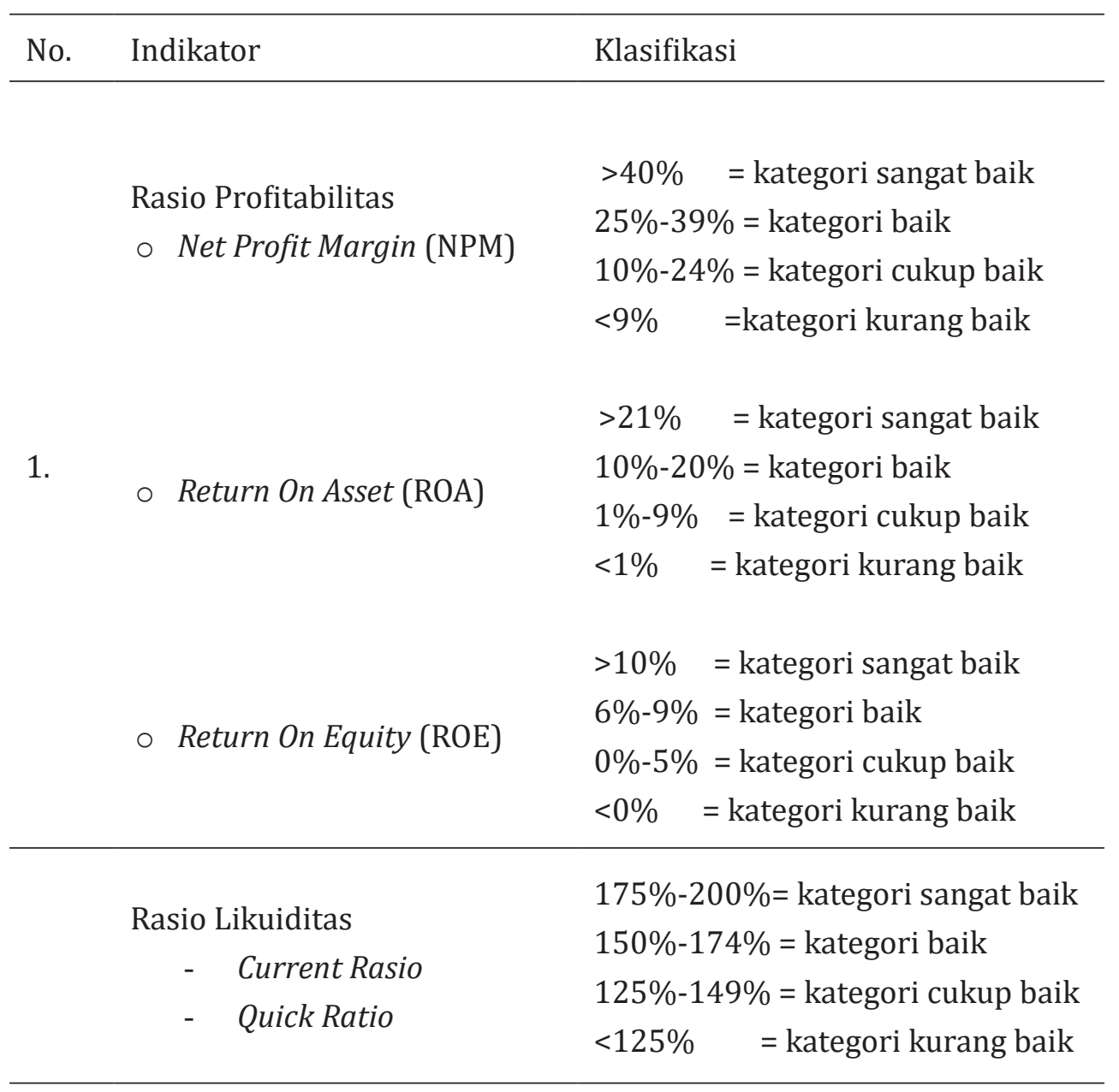




\section{HASIL DAN PEMBAHASAN}

\section{Data Laporan Keuangan UD Al-Qudsyi Manggis pada Periode 2018-2020}

Data laporan keuangan di perusahaan Al-Qudsyi Manggis dari tahun 2018 sampai dengan 2020 mengalami peningkatan dikarenakan setiap tahun perusahaan menambah jumlah tenaga kerja dengan merekrut sales untuk meningkatkan pendapatan perusahaan. Sales menjadi kunci utama dari naik turunnya penjualan produk, jika sales bisa meningkatkan penjualan maka pendapatan perusahaan juga meningkat begitu juga sebaliknya. Untuk mengetahui laporan keuangan UD AlQudsyi Manggis maka, dapat dilihat pada tabel 2 dan 3 mengenai laporan neraca dan laba/rugi periode 2018-2020 di UD Al-Qudsy Manggis Ngembalrejo Kudus.

\section{Laporan Neraca}

Tabel 2 Neraca

UD AL-QUDSYI MANGGIS

Per 31 Desember 2018-2020

\begin{tabular}{lrrr}
\hline \multicolumn{1}{c}{ Keterangan } & $\mathbf{2 0 1 8}$ & \multicolumn{1}{c}{$\mathbf{2 0 1 9}$} & \multicolumn{1}{c}{$\mathbf{2 0 2 0}$} \\
\hline Aktiva Lancar: & & & \\
\hline Kas & 1.388 .637 .375 & 1.549 .579 .375 & 1.758 .667 .425 \\
\hline Piutang Dagang & 2.400 .000 .000 & 2.640 .000 .000 & 2.880 .000 .000 \\
\hline Persediaan Barang Dagangan & 192.000 .000 & 216.000 .000 & 240.000 .000 \\
\hline Total Aktiva Lancar & $\mathbf{3 . 9 8 0 . 6 3 7 . 3 7 5}$ & $\mathbf{4 . 4 0 5 . 5 7 9 . 3 7 5}$ & $\mathbf{4 . 8 7 8 . 6 6 7 . 4 2 5}$ \\
\hline Aktiva Tetap: & & & \\
\hline Tanah & 975.000 .000 & 1.020 .000 .000 & 1.050 .000 .000 \\
\hline Bangunan & 400.000 .000 & 450.000 .000 & 500.000 .000 \\
\hline Transportasi & 800.000 .000 & 880.000 .000 & 960.000 .000 \\
\hline Alat \& Mesin & 50.000 .000 & 75.000 .000 & 100.000 .000 \\
\hline Penyusutan & 80.000 .000 & 90.000 .000 & 100.000 .000 \\
\hline Total Aktiva Tetap & $\mathbf{2 . 1 4 5 . 0 0 0 . 0 0 0}$ & $\mathbf{2 . 3 3 5 . 0 0 0 . 0 0 0}$ & $\mathbf{2 . 5 1 0 . 0 0 0 . 0 0 0}$ \\
\hline Total Aktiva & $\mathbf{6 . 1 2 5 . 6 3 7 . 3 7 5}$ & $\mathbf{6 . 7 4 0 . 5 7 9 . 3 7 5}$ & $\mathbf{7 . 3 8 8 . 6 6 7 . 4 2 5}$ \\
\hline Hutang Lancar: & & & \\
\hline Hutang Dagang & 398.000 .000 & 420.000 .000 & 435.000 .000 \\
\hline Gaji yang akan dibayar & 1.050 .000 .000 & 1.100 .000 .000 & 1.200 .000 .000 \\
\hline Hutang Lainnya & 74.500 .000 & 76.000 .000 & 78.500 .000 \\
\hline Total Hutang Lancar & $\mathbf{1 . 5 2 2 . 5 0 0 . 0 0 0}$ & $\mathbf{1 . 5 9 6 . 0 0 0 . 0 0 0}$ & $\mathbf{1 . 7 1 3 . 5 0 0 . 0 0 0}$ \\
\hline Modal: & & & \\
\hline Modal Disetor & 980.000 .000 & 1.100 .500 .000 & 1.150 .000 .000 \\
\hline
\end{tabular}


Widi Savitri Andriasari, A. Syifaul Aziz, Siti Lailatu N., Nia Monica Febriana, dan Peni Safitri

\begin{tabular}{lrrr}
\hline Laba Ditahan & 845.862 .625 & 944.920 .625 & 986.137 .425 \\
\hline Laba Tahun Berjalan & 2.777 .274 .750 & 3.099 .158 .750 & 3.539 .030 .000 \\
\hline Total Modal & $\mathbf{4 . 6 0 3 . 1 3 7 . 3 7 5}$ & $\mathbf{5 . 1 4 4 . 5 7 9 . 3 7 5}$ & $\mathbf{5 . 6 7 5 . 1 6 7 . 4 2 5}$ \\
\hline Total Passiva & $\mathbf{6 . 1 2 5 . 6 3 7 . 3 7 5}$ & $\mathbf{6 . 7 4 0 . 5 7 9 . 3 7 5}$ & $\mathbf{7 . 3 8 8 . 6 6 7 . 4 2 5}$ \\
\hline
\end{tabular}

Berdasarkan tabel 2 di atas disimpulkan bahwa jumlah aktiva di perusahaan UD Al-Qudsyi Manggis pada tahun 2018 sebesar Rp. 6.125.637.375, tahun 2019 sebesar Rp. 6.740.579.375, tahun 2020 sebesar Rp. 7.388.667.425. Dalam tabel 2 diatas total passiva sama dengan total aktiva dengan begitu laporan neraca di UD AlQudsyi Manggis sudah seimbang. Dimana setiap tahunnya mengalami peningkatan terus, tahun 2018-2019 meningkat sebesar Rp. 614.942 .000 selanjutnya ditahun 2019-2020 juga mengalami kenaikan sebesar Rp. 640.089.048. Sehingga dapat diketahui bahwa kenaikan ditahun 2019-2020 lebih tinggi daripada tahun 2018 - 2019. Adanya peningkatan aktiva setiap tahunnya dikarenakan setiap tahun perusahaan Al-Qudsyi manggis mempunyai tambahan tenaga kerja sales. sehingga membuat pendapatan hasil penjualan meningkat tiap tahunnya.

\section{Laporan Laba / Rugi}

Tabel 3 Laporan Laba/Rugi

UD AL-QUDSYI MANGGIS

Per 31 Desember 2018-2020

\begin{tabular}{lrrr}
\hline \multicolumn{1}{c}{ Keterangan } & $\mathbf{2 0 1 8}$ & \multicolumn{1}{c}{$\mathbf{2 0 1 9}$} & \multicolumn{1}{c}{$\mathbf{2 0 2 0}$} \\
\hline & & & \\
\hline Penjualan & 5.680 .050 .000 & 6.221 .750 .000 & 6.751 .530 .000 \\
\hline Harga Pokok Penjualan & 2.300 .500 .000 & 2.450 .000 .000 & 2.500 .500 .000 \\
\hline laba Kotor & $\mathbf{3 . 3 7 9 . 5 5 0 . 0 0 0}$ & $\mathbf{3 . 7 7 1 . 7 5 0 . 0 0 0}$ & $\mathbf{4 . 2 5 1 . 0 3 0 . 0 0 0}$ \\
\hline & & & \\
\hline Biaya Operasional: & & & \\
\hline Biaya Penjualan & 360.000 .000 & 396.000 .000 & 432.000 .000 \\
\hline Biaya Penyusutan & 140.500 .000 & 95.000 .000 & 100.000 .000 \\
\hline Biaya Administrasi \& Umum & $\mathbf{5 8 4 . 5 0 0 . 0 0 0}$ & $\mathbf{6 5 3 . 0 0 0 . 0 0 0}$ & $\mathbf{7 1 2 . 0 0 0 . 0 0 0}$ \\
\hline total baiya Operasional & $\mathbf{2 . 7 9 5 . 0 5 0 . 0 0 0}$ & $\mathbf{3 . 1 1 8 . 7 5 0 . 0 0 0}$ & $\mathbf{3 . 5 3 9 . 0 3 0 . 0 0 0}$ \\
\hline Laba Sebelum Pajak & 17.775 .250 & 19.591 .250 & 21.695 .150 \\
\hline Pajak Penghasilan & $\mathbf{2 . 7 7 7 . 2 7 4 . 7 5 0}$ & $\mathbf{3 . 0 9 9 . 1 5 8 . 7 5 0}$ & $\mathbf{3 . 5 1 7 . 3 3 4 . 8 5 0}$ \\
\hline Laba Bersih & & & \\
\hline
\end{tabular}


Pada Tabel 3 dapat dilihat bahwa UD Al-Qudsyi Manggis di desa ngembalrejo kudus memperoleh laba pada tahun 2018 sebesar Rp. 2.777.274.750, pada tahun 2019 sebesar Rp. 3.099.158.750, pada tahun 2020 sebesar Rp. 3.517.334.850. Setiap tahunnya mengalami peningkatan pada tahun 2018-2019 sebesar Rp. 321.884 .000 dan ditahun 2019-2020 sebesar Rp.418.176.100.

\section{Rasio Profitabilitas UD Al-Qudsyi Manggis Laporan Keuangan Pada Periode 2018 - 2020}

Berdasarkan hasil laporan neraca dan laba/rugi UD Al-Qudsyi Manggis pada tabel 2 dan 3, maka pembahasan selanjutnya yaitu analisa laporan keuangan dengan menggunakan analisa rasio profitabilitas. Dalam menganalisa rasio profitabilitas selama periode tersebut maka data yang diperlukan adalah laporan neraca dan laba/rugi setiap tiga periode per tanggal 31 Desember ditahun 2018-2020. Dengan melihat adanya perubahan yang terjadi disetiap aliran neraca, maka tingkat rasio profitabilitas UD Al-Qudsyi Manggis setiap tahunnya dapat diketahui. Berikut ini perhitungan persentase tingkat rasio profitabilitas selama periode 2018-2020 pada UD Al-Qudsyi Manggis sebagai berikut:

1. Net Provit Margin (NPM)

$$
\begin{aligned}
& \text { NPM }=\frac{\text { Laba Bersih }}{\text { Pendapatan }} \times 100 \% \\
& \text { Tahun } 2018=\frac{2.777 .274 .750}{5.680 .050 .000} \times 100 \% \\
& \quad=48,90 \% \\
& \text { Tahun } 2019=\frac{3.099 .158 .750}{6.221 .750 .000} \times 100 \% \\
& \quad=49,80 \% \\
& \text { Tahun } 2020=\frac{3.517 .334 .850}{6.751 .530 .000} \times 100 \% \\
& =52 \%
\end{aligned}
$$


2. Return On Asset (ROA)

$$
\begin{aligned}
& \text { ROA }=\frac{\text { Laba Bersih }}{\text { Total Aktiva }} \times 100 \% \\
& \text { Tahun } 2018=\frac{2.777 .274 .750}{6.125 .637 .375} \times 100 \% \\
& =45,33 \% \\
& \text { Tahun } 2019=\frac{3.099 .158 .750}{6.740 .579 .375} \times 100 \% \\
& \text { Tahun } 2020=\frac{3.517 .334 .850}{7.388 .667 .425} \times 100 \% \\
& =47,60 \%
\end{aligned}
$$

3. Return On Equit (ROE)

$$
\begin{aligned}
& \text { ROE }=\frac{\text { Laba Bersih }}{\text { Rata }- \text { rata Ekuitas }} \times 100 \\
& \text { Tahun } 2018=\frac{2.777 .274 .750}{4.603 .137 .375} \times 100 \% \\
& =60,33 \% \\
& \text { Tahun } 2019=\frac{3.099 .158 .750}{5.144 .579 .375} \times 100 \% \\
& \text { Tahun } 2020=\frac{3.517 .334 .850}{5.675 .167 .425} \times 100 \% \\
& =61,91 \%
\end{aligned}
$$

Dapat dilihat hasil dari perhitungan rasio profitabilitas diatas berdasarkan laporan keuangan UD Al-Qudsyi Manggis ditahun 2018-2020 akan terlihat lebih jelas dengan tabel 4 berikut: 
Tabel 4 Perhitungan Rasio Profitabilitas

UD AL-QUDSYI MANGGIS

TAHUN 2018-2020

\begin{tabular}{lrrrr}
\hline \multirow{2}{*}{ Profitabilitas } & \multicolumn{3}{c}{ Tahun } & \multirow{2}{*}{ Rata-rata } \\
\cline { 2 - 4 } & $\mathbf{2 0 1 8}$ & $\mathbf{2 0 1 9}$ & $\mathbf{2 0 2 0}$ & \\
\hline NPM \% & $48,90 \%$ & $49,80 \%$ & $52 \%$ & $50,23 \%$ \\
\hline ROA \% & $45,33 \%$ & $46 \%$ & $47,60 \%$ & $46,30 \%$ \\
\hline ROE \% & $60,33 \%$ & $60,24 \%$ & $61,91 \%$ & $60,83 \%$ \\
\hline
\end{tabular}

Berdasarkan tabel 4 diatas net provit margin yang diperoleh dengan membandingkan antara laba bersih dengan penjualan atau pendapatan usaha tahun 2018-2020 masing-masing didapat 48,90\% tahun 2018, 49,80\% tahun 2019, dan sebesar 52\% ditahun 2020. Hasil perbandingan antara laba bersih dengan total aktiva atau yang sering disebut return on asset yang didapat ditahun 2018 yaitu 45,33\%, 2019 sebesar 46\%, dan ditahun 2020 sebesar 47,60\%. Untuk return on equity diperoleh dengan membandingkan antara laba bersih dan jumlah modal sehingga diperoleh masing-masing periode sebesar 60,33\% tahun 2018, 60,24\% diahun 2019 , dan 61,91\% pada tahun 2020. Jika dirata-rata dari tahun 2018-2020 hasil analisa rasio profitabilitas didapat net provit margin sebesar $50,23 \%$, return on asset $46,30 \%$, dan return on equity sebesar $60,83 \%$. Dari ketiga rasio profitabilitas tersebut yang paling tinggi adalah return on asset.

\section{Rasio Likuiditas UD Al-Qudsyi Manggis Laporan Keuangan Pada Periode 2018 $-2020$}

\section{Current Ratio (CR)}

Current Ratio biasanya digunakan untuk menghitung sejauh mana kemampuan perusahaan UD Al-Qudsy Manggis bisa menjamin kewajiban lancarnya melalui aktiva atau asset lancar. Jika perbandingan antara aktiva lancar dan hutang lancar semakin besar maka tingkat kemampuan perusahaan dalam menyeleseikan kewajiban atau hutang jangka pendek semakin tinggi. Berikut tabel dari data perhitungan current ratio (CR) di UD Al-Qudsy Manggis: 
Tabel 5 Perhitungan Current Ratio

\begin{tabular}{crrr}
\hline Tahun & Aktiva Lancar & Hutang Lancar & \multicolumn{1}{c}{ CR \% } \\
\hline 2018 & 3.980 .637 .375 & 1.522 .500 .000 & $261,45 \%$ \\
\hline 2019 & 4.405 .579 .375 & 1.596 .000 .000 & $276 \%$ \\
\hline 2020 & 4.878 .667 .425 & 1.713 .500 .000 & $284,71 \%$ \\
\hline Rata-rata & 4.421 .628 .058 & 1.610 .666 .667 & $274,52 \%$ \\
\hline
\end{tabular}

Pada tabel 5 diatas tentang analisia current ratio UD Al-Qudsy Manggis diperoleh kesimpulan bahwa current ratio yang paling baik dari periode 2018-2020 adalah ditahun 2020 sebesar 284,71\%. Dalam arti lain UD AlQudsy Manggis pada tahun tersebut yaitu tahun 2020 mampu menunjukkan kemampuannya yang paling baik untuk bisa memenuhi kewajiban atau hutang jangka pendeknya.

\section{Quick Ratio (QR)}

Untuk mengukur kemampuan perusahaan dalam memenuhi kewajiban atau hutang jangka pendeknya dengan tidak menggunakan nilai penjualaan dan persediaan dinamakan quick ratio atau sering disebut rasio cepat. Rumus untuk menghitung quick ratio adalah akvita lancar dikurangi dengan jumlah persediaan. Didalam aktiva lancar nilai likuiditas persediaan rendah dan juga mudah untuk menimbulkan terjadinya kerugian apabila terjadi likuid dalam perusahaan. Sehingga rasio likuiditas adalah rasio yang paling baik untuk mengukur kemampuan perusahaan dalam memenuhi kewajiban lancar dengan menggunakan aktiva lancar. Berikut tabel data quick ratio pada UD AlQudsy Manggis:

Tabel 6 Perhitungan Quick Ratio

\begin{tabular}{crrrr}
\hline Tahun & Aktiva Lancar & Hutang Lancar & Persediaan & Quick Ratio \% \\
\hline 2018 & 3.980 .637 .375 & 1.522 .500 .000 & 192.000 .000 & $248,84 \%$ \\
\hline 2019 & 4.405 .579 .375 & 1.596 .000 .000 & 216.000 .000 & $262,50 \%$ \\
\hline 2020 & 4.878 .667 .425 & 1.713 .500 .000 & 240.000 .000 & $270,71 \%$ \\
\hline Rata-rata & 4.421 .628 .058 & 1.610 .666 .667 & 216.000 .000 & $260,68 \%$ \\
\hline
\end{tabular}

Berdasarkan tabel 6 dapat dilihat hasil analisia rasio likuiditas quick ratio tersebut kesimpulannya quick ratio dari UD Al-Qudsy Manggis bersifat stabil, dari tahun 2018 sebesar 248,84\% mengalami kenaikan terus-menerus 2019 
menjadi 262,50\% dan ditahun 2020 naik hingga 270,71\%. Jika ketiga periode tersebut dirata-rata maka didapat $260,68 \%$.

\section{Analisis Kinerja Keuangan UD Al-Qudsy Manggis}

Analisis kinerja keuangan UD Al-Qudsy Manggis berdasarkan perhitungan dari rasio profitabilitas dan likuiditas yang sudah dijelaskan sebelumnya, analisis hasil kinerja keuangan UD Al-Qudsy selama periode tahun 2018-2020 berdasarkan UU No.14 tahun 2009 tentang keputusan menteri negara koperasi dan Usaha Kecil dan Menengah (UMK) mengenai analisa indeks kinerja keuangan adalah sebagai berikut:

Table 7 Hasil Analisis Rasio

\begin{tabular}{clrc}
\hline No & \multicolumn{1}{c}{ Indikator } & \multicolumn{1}{c}{$\begin{array}{c}\text { Rata-rata } \\
\mathbf{2 0 1 8 - 2 0 2 0} \%\end{array}$} & Kategori \\
\hline 1 & Net Profit Margin & $50,23 \%$ & Sangat Baik \\
\hline 2 & Return On Asset & $46,30 \%$ & Sangat Baik \\
\hline 3 & Return On Equity & $60,84 \%$ & Sangat Baik \\
\hline 4 & Current Ratio & $274,52 \%$ & Sangat Baik \\
\hline 5 & Quick Ratio & $260,68 \%$ & Sangat Baik \\
\hline
\end{tabular}

Analisis kinerja keuangan Rasio Profitabilitas dari UD Al-Qudsy Manggis, net profit margin (NPM) tahun 2018 sebesar 48,90\% ini merupakan nilai yang cukup baik dimana setiap penjualan mendapatkan laba Rp 489,-dengan syarat penjualan barang sebersar Rp 1000,- ini semua sudah dikatakan bagus mengingat UD AlQudsy Manggis pada tahun 2018 belum bisa dikatakan usaha yang maju pesat sarana promosi juga masih menggunakan media konvensional. Pada tahun 2019 net profit margin meningkat sebesar $49,80 \%$ maka jika dihitung akan mendapatkan keuntungan senilai Rp 498,- hasil tersebut lebih tinggi dari tahun sebelumnya. Dan untuk tahun 2020 UD Al-Qudsy Manggis mampu meningkatkan net profit margin sebesar 52,00\% dengan begitu perusahaan tersebut mampu untuk memajukan usahanya terlihat setiap periode tahun persentasenya meningkat terus menerus. Menurut indeks kinerja keuangan yang termuat dalam UU No. 14 tahun 2009 dapat ditarik kesimpulan bahwa kinerja keuangan UD Al-Qudsy Manggis sudah bisa disebut sangat baik karena bisa dikatakan sangat baik setidaknya harus mempunyai persentase $40 \%$. Didalam perhitungan persentase rata-rata net profit margin UD Al-Qudsy Manggis sebesar 50,23\% itu berarti kemampuan perusahaan untuk menghasilkan keuntungan melalui penjualan sudah sangat baik mengingat setiap periode tahun mengalami peningkatan. 
Return On Asset (ROA) perusahaan UD Al-Qudsy Manggis dari periode 2018 sampi dengan periode 2020 juga mengalami peningkatan terus. Sesui yang disajikan pada tabel 7 rata-rata return on asset UD Al-Qudsy Manggis sebesar 46,30 melihat dari hasil tersebut maka perusahaan tersebut mampu menggunakan aktivanya dengan baik sehingga bisa menghasilkan keuntungan yang meningkat.

Analisa return on equity (ROE) merupakan analisa yang digunakan untuk mengukur persentase kemampuan perusahaan UD Al-Qudsy Manggis mendapatkan laba dengan mengandalkan modal sendiri yang telah dikelola oleh pihak pelaku usaha. Sesuai tabel 7 tentang hasil rata-rata analisis rasio, dapat diketahui bahwa hasil rata-rata return on equity selama periode 2018 sampai 2020 pada UD AlQudsy Manggis sebesar 60,83\%, jika mengacu pada indeks kinerja keuangan bisa dikategorikan dalam keadaan sangat baik. Meningkatnya return on equity disetiap tahunnya bisa terjadi karena adanya penambahahan modal awal yang dilakukan oleh pihak usaha tersebut, hal ini dapat dilihat pada penjualan yang ditidak seimbang dengan penambahan modal sehingga ini sangat mempengaruhi laba bersih. Nilai rata-rata return on equity sebesar $60,83 \%$ membuat bisa dikatakan UD Al-Qudsy Manggis sudah baik dalam menghasilkan keuntungan.

Berdasarkan hasil analisis rasio likuiditas current ratio pada tabel 5 menunjukkan tingkat current ratio pada tahun 2018 sebesar 261,45\% ini sudah bisa dikatakan sangat baik Dari hasil analisis rasio pada tabel 7 diatas, diketahui hasilnya dimana angka current ratio pada tahun 2018 berada pada angka yang sangat baik kemudian pada tahun 2019 meningkat sebesar 276\% dan ditahun 2020 naik lagi sebesar 284,71\%. Dapat disimpulkan bahwa UD Al-Qudsy Manggis mempunyai kemampuan yang sangat baik dalam memenuhi kewajiban atau hutang jangka pendeknya. UD Al-Qudsy Manggis sudah mampu meningkatkan sebesar 175\% dalam indeks kinerja keuangan dikategorikan sangat baik.

Analisa likuiditas quick ratio yang terlihat pada tabel 6 yaitu sebesar 248,84\% ditahun 2018 kemudian mengalami peningkatan ditahun 2019 sebesar 262,50\% ini merupakan peningkatan yang lebih tinggi dibandingkan tahun 2020 hanya meningkat sebesar 270,71\%. Jika dirata-rata keseluruhan selama periode tahun 2018 sampai tahun 2020 rata-rata quick ratio yang didapat adalah 260,68\%. Jika menurut indeks kinerja keuangan yang tertuang dalam UU No. 14 tahun 2009 yang menyatakan bahwa jika hasil quick ratio sebesar 200\% atau tidak lebih dikatakan sangat baik, maka mengingat UD Al-Qudsyi Manggis memiliki rata-rata sebesar $260,68 \%$ bisa dikatakan sangat baik dan juga bisa dikatkan over liquid. 


\section{KESIMPULAN}

Berdasarkan hasil penelitian dan analisis data pada kinerja keuangan UD AlQudsy Manggis berdasarkan perhitungan rasio profitabilitas dan rasio likuiditas pada periode tahun 2018 sampai dengan tahun 2020 diperoleh hasil sebagai berikut:

\begin{tabular}{clrc}
\hline No & \multicolumn{1}{c}{ Indikator } & $\begin{array}{r}\text { Rata-rata } \\
\mathbf{2 0 1 8 - 2 0 2 0} \%\end{array}$ & Kategori \\
\hline 1 & Net Profit Margin & $50,23 \%$ & Sangat Baik \\
\hline 2 & Return On Asset & $46,30 \%$ & Sangat Baik \\
\hline 3 & Return On Equity & $60,84 \%$ & Sangat Baik \\
\hline 4 & Current Ratio & $274,52 \%$ & Sangat Baik \\
\hline 5 & Quick Ratio & $260,68 \%$ & Sangat Baik \\
\hline
\end{tabular}

Diperoleh hasil analisis likuiditas yakni Current Ratio dan Quick Ratio pada UD Al-Qudsy Manggis dalam keadaan sangat baik, dari hasil perhitungan Current Ratio bisa dilihat bahwa kemampuan perusahaan untuk memenuhi kewajiban jangka pendeknya sudah sangat baik dan cukup kuat karena jaminan untuk mampu memenuhi kewajiban jangka pendeknya cukup besar angkanya. Sedangkan perhitungan Quick Ratio menunjukan angka yang sangat baik juga bisa dikategorikan over liquid yaitu 322,13\% dimana menurut UU No 14 tahun 2009 angka quick ratio harus berada setidaknya sama atau tidak boleh lebih besar dari 200\%. Pada periode tahun 2018 angka quick ratio dari UD Al-Qudsy Manggis sangat baik yaitu 248,84\%, kemudian mengalami kenaikan menjadi $262,50 \%$ pada tahun 2019 , dan $270,71 \%$ pada tahun 2020. Dari sini bisa disimpulkan bahwa kinerja keuangan UD Al-Qudsy Manggis dilihat dari Current Ratio dan Quick Ratio bisa dikatakan baik tingkat likuiditasnya, dengan tingkat rasio tersebut menunjukkan bahwa kas cukup mampu menjamin kewajiban-kewajiban jangka pendeknya.

Selain itu, analisis kinerja keuangan Rasio Profitabilitas dari UD Al-Qudsy Manggis periode tahun 2018 sampai 2020 mengalami peningkatan. Tingkat profitabilitas diukur dengan perhitungan Net Profit Margin (NPM), Return On Asset (ROA) dan Return On Equity (ROE). Net Profit Margin yang diperoleh dari hasil perbandingan antara laba bersih dengan pendapatan tahun 2018 sebesar 48,90\%, tahun 2019 sebesar 49,80\%, tahun 2020 sebesar 52\%. Return On Asset yang diperoleh dari hasil perbandingan laba bersih dengan total aktiva, tahun 2018 sebesar 45,33\%, tahun 2019 sebesar 46\%, tahun 2020 sebesar 47,60\%. Return On Equity yang diperoleh dari hasil perbandingan laba bersih dengan total modal 
tahun 2018 sebesar 60,33\%, tahun 2019 sebesar 60,24\%, tahun 2020 sebesar 61,91\%. Dari ketiga rasio tersebut diperoleh rata-rata Net Profit Margin 50,23\%, Return On Asset 46,30\%, Return On Equity 60,83\%. Rata-rata tertinggi adalah pada rasio profitabilitan Return On Asset. Dilihat dari indikator kinerja keuangan dengan berdasarkan pada keputusan menteri negara koperasi dan Usaha Kecil dan Menengah (UMK) UU No.14 tahun 2009 dapat disimpulkan bahwa tingkat profitabilitas UD AlQudsy Manggis dalam kondisi sangat baik karena nilai indikator diatas standarnya. Kemampuan dalam menghasilkan laba dengan modal sendiri yang diinvestasikan kedalam usahanya sangat tinggi serta kemampuan yang dimiliki perusahaan dalam menghasilkan laba sudah memuaskan. 


\section{DAFTAR PUSTAKA}

Asrof Syafi'I. (2005). Metodologi Penelitian Pendidikan. Surabaya: Elkaf.

Abdurahmat Fathoni, Metode Penelitian \& Teknik Penyusunan Skripsi (Jakarta: Rineka Cipta, 2005), 57.

Andjarwati, T., \& Nur hakim, V. (2018). Pengaruh Saluran Distribusi Dan Personal Selling Terhadap Volume Penjualan Pt. Borwita Citra Prima Sidoarjo. JEM17: Jurnal Ekonomi Manajemen, 2(2). https://doi.org/10.30996/jem17.v2i2.1198

Anwar, Y., Yunsepa, Y., \& Meliyani, R. (2020). Analisis Rasio Likuiditas Dan Rasio Profitabilitas Pada Perusahaan Daerah Air Minum Kabupaten Ogan Komering Ulu. Jurnal Ecoment Global Vol 5(1), 56. https://

Audina, V. N., \& Khotimah, H. (2021). Jurnal Penelitian Implementasi Akuntansi (JPIA ) Vol 2(1). 100-120.

Khamidah, F. I. (2015). Analisis Kinerja Keungan Berdasarkan Rassio Profitabilitas Dan Likuiditas Pada LBB SSC Surabaya. Fakultas Ekonomi,Unibersitas Narotama, $1-19$.

Tarumasely, S., \& Siswati, S. (2021). Analisis Rasio Profitabilitas Pada PDAM Tirta Merapi Kabupaten Klaten Berdasarkan Operating Profit Margin , Net Profit Margin, Return On Asset dan Return On Equity Penelitian ini dilakukan untuk mengetahui analisis rasio profitabilitas PDAM Tirta Merapi . XV(1), 70-81.

Utama, Erpan Rizky, I. S. dan K. A. (2019). Analisis kinerja keuangan menggunakan perhitungan rasio keuangan (studi pada ukm gugah selera desa mantuil kec. muara harus kabupaten tabalong). 2(14), 78-94. 
halaman ini sengaja untuk dikosongkan 